"Some leading causes of emerging rural poultry small and medium enterprises failure in South Africa"

\begin{tabular}{ll} 
AUTHORS & $\begin{array}{l}\text { Mahlatse Leakalala Moloto } \\
\text { Solly Matshonisa Seeletse }\end{array}$ \\
Mahlatse Leakalala Moloto and Solly Matshonisa Seeletse (2016). Some leading \\
ARTICLE INFO & $\begin{array}{l}\text { causes of emerging rural poultry small and medium enterprises failure in South } \\
\text { Africa. Environmental Economics, 7(3), 25-32. doi:10.21511/ee.07(3).2016.03 }\end{array}$ \\
\hline DOI & http://dx.doi.org/10.21511/ee.07(3).2016.03 \\
\hline RELEASED ON & Friday, 21 October 2016 \\
\hline JOURNAL & "Environmental Economics" \\
\hline FOUNDER & LLC "Consulting Publishing Company "Business Perspectives"
\end{tabular}

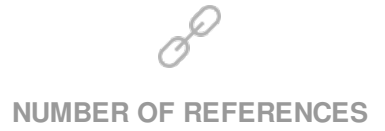

0

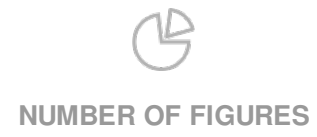

0

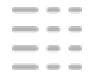

NUMBER OF TABLES

0

(C) The author(s) 2022. This publication is an open access article. 


\title{
Some leading causes of emerging rural poultry small and medium enterprises failure in South Africa
}

\begin{abstract}
This study examines the factors that cause failures of many South African rural small and medium enterprises (SMEs) in poultry business. The research method was qualitative phenomenology using in-depth, semi-structured interviews to explore the factors considered by rural chicken SMEs owners to be causes of their business difficulties. The study revealed that these entrepreneurships knew chicken business only from the home-grown chickens, and the local poultry was usually providing only meat. Compared to the local chickens that were cheap to acquire and nurture, the commercial ones had to be purchased, nourished with purchased foods, supported with electricity light at night, and still, some died. It was much cheaper to raise indigenous chickens. The results indicate that rural poultry SMEs owners did not know that buying a commercial chick carries benefits that range from eggs, feathers, meat, and other chicken products. Also, after purchasing each chick, there are more additional investments needed to maintain the market standard. The study enlightens chicken entrepreneurs that they should, first, learn the insight of business, the poultry industry, and the context of the business they wish to pursue.
\end{abstract}

Keywords: competition, formal market, informal business, SMEs, poultry, rural, tax.

JEL Classification: Q13, O17.

\section{Introduction}

This paper exposes challenges of small and medium enterprises (SMEs) in the rural areas of South Africa in the poultry business. Rural SMEs in the poultry business struggle to survive due to lack of insight in the poultry business. Many of them have little or no understanding of formal business management (Thwala, Pillay \& Sargeant, 2001). The rural business management environment lacked sophistication, as there was neither competition nor costs of investments. Most chickens they used as business stock had been inherited, or purchased at very low prices. The new formal businesses have to make a profit in order to survive and thrive. Many rural SMEs transformed from survivalists and micro-businesses (SMB) because of successes and experiences gathered in rural settings. They entered a more dynamic formal market possibly naïve due to lack of formal business training, and lack of previous exposure to the mainstream business. Like most SMEs that fail in large numbers in their first three years of inception (Rogerson, 2004), poultry SMEs also fail in similar patterns. The formal market might have expensive investments and tough competition. This study examined the factors of difficulty for rural SMEs in the poultry business.

In the rural setting, business players are few and simple with limited and ineffective competition (Dzansi, 2004). Chicken farmers of indigenous chickens inherit poultry stock at no cost. Also, looking after the chickens is cheap, as the indigenous chickens

(C) Mahlatse Leakalala Moloto, Solly Matshonisa Seeletse, 2016. Mahlatse Leakalala Moloto, Department of Statistics and Operations Research, Sefako Makgatho Health Sciences University, South Africa. Solly Matshonisa Seeletse, Ph.D., DBA, Professor, Department of Statistics and Operations Research, Sefako Makgatho Health Sciences University, South Africa. can fend for themselves. In mainstream business, on the other hand, competition is an important business aspect. Managing a business becomes expensive for SMEs, as some have to pay tax for the first time due to registration conditions. Thus, investment costs and other business expenses for rural poultry SMEs are likely going to delay the entrepreneurial activity and progress.

Generally, many entrepreneurs have business ideas, but would sometimes lack business knowledge and skill. Many of those who have knowledge and skill would want to start big, or join forces with big business. Due to their deficient knowledge and skill, any complexities emerging, such as competition and extra expenses, are likely going to strain their SMEs.

\section{Literature review}

Transition from SMBs seems easy and straightforward for growth of business. According to several authors (Abor \& Quartey, 2010, Gagoitseope \& Pansiri, 2012; Gill \& Biger, 2012), they face many challenges that impede their growth and development beyond their meagre modes of business activity. Timmons and Spinelli (2004) enlighten that over the past five to six decades, the failure rate in emerging and transforming businesses has been very high. This failure rate was over an average of $45 \%$ for emerging businesses. Ladzani and Van Vuuren (2002) established that the bulk of these failures occurs mainly in the first three years. No single cause or problem can be attributed to these failures, as the problems encountered by these businesses are countless.

However, according to Brink, Cant and Ligthelm (2003), they can be categorized into environmental, financial or managerial classes. 
The purpose of the study was to determine the challenges of rural poultry SMEs and the causes of the challenges.

\section{Profit focus of SMEs}

Naturally, there are anticipated business difficulties for a rural poultry farmer. However, for growth and sustainability, the profit-first approach is vital in business. Agle et al. (2008) also highlight that profit maximization is of interest in any business. International research shows various factors that influence business decisions (Mantel, 2005). Still, profit is a common factor for all businesses. Many factors, in addition to profits, influence the decision processes and affect the direction chosen for the business by the decision-maker (Zyphur, 2006).

The decision-makers' choices in business can affect inclusive organizational ethics and attitude (Cullinan et al., 2008). Appreciating the influences and profit considerations of the decision-makers in SMEs enhances the knowledge of management and leadership. Identifying effects and profit priorities in making decisions may lead to fundamental changes in management and leadership theory for SMEs. Argyris (1998) argued that effective modern leadership requires leaders to understand the decision-making processes and their influences in generating profit. The choices and decisions made by the owners/managers of SMEs may reflect different influences, and may affect the operations' effectiveness. These may, in turn, affect profits. The influences may be deliberately oriented toward some views or they may involve an indirect or subconscious effect (Hauser et al., 2007). Whichever way, profit is a principal concern of business. The rural poultry SMEs as well can only survive if they make profits.

\section{Conjectural background}

There has long been interest in business and corporate environments (Lepoutre \& Heene, 2006; Mark-Ungericht \& Weiskopf, 2007). Discussions on business have focused on large corporations or large organizations (Perrini et al., 2007; Revell \& Blackburn, 2007). Additional research is required on practices and performance in SMEs (Moore \& Spence, 2006) and on influences on the decisionmaking of SME owner-managers (Parboteeah et al., 2008). Recently, studies have begun to investigate SMEs as distinct entities from large ones (Jenkins, 2006). SMEs differ in expectations from large ones and may vary with regard to influences on the decision-making processes. Research focus on SMEs has not gone considerably to rural SMEs. Neither has it stretched adequately to chicken farming. The rural poultry SMEs is an even more 'hidden spot'. It is even more limited in developing countries, of which South Africa is one. This paper, therefore, examines an area with virtually no academic attention (Moore \& Spence, 2006). Its findings would add to accrued scholarly work, as it fills missing gaps in knowledge by investigating a research area to fill a void in existing information (Creswell, 2014). It enlightens on an area of poultry SMEs in rural South Africa which contributes to confrontation of challenges for small business operations.

\section{Dynamics of chickens in poultry business}

4.1. Improving the soil for chickens. Chickens are famous for supplying people with meat, eggs and feathers. However, according to Appleby, Mench and Hughes (2004), chickens have many more roles to play, particularly in a food garden. They can be used to clear weeds, eat weed seeds, eat insect pests, fertilize the soil with their faeces, dig over the soil surface and mix it with faeces. An effective system to ensure they play these roles is a portable house called a chicken tractor, which keeps and moves a flock of about twelve chickens every two weeks or so to a new position in the food garden (Foer, 2009). In each chicken plant, they perform the roles listed. In this way, they prepare the area to plant with new crops. Grass full of seed for sheet dressing can be distributed on the ground for the chickens to deseed. These facts are virtually unknown in business practices of many emerging rural poultry SMEs.

4.2. Chicken breeds. The different breeds of chickens are generally categorized as dual-purpose, broiler, layer and indigenous (Chen et al., 2002; Deeb, Shlosberg \& Cahaner, 2002). Dual-purpose are pure-breeds producing eggs and meat. Broiler breeds produce meat and layer breeds are farmed for producing eggs. Both are cross-breeds called hybrids. Broilers grow fast and are slaughtered at an early age. Layers produce many eggs (Sherwin, Richards \& Nicol, 2010). Chicks of the same hybrid do not grow up exactly the same as their parents. Hence, new hybrid chicks should be bought from a skilful supplier. Current indigenous South African chickens are currently typically a blend of broiler and layer breeds, because these birds have bred freely. However, they usually grow well in their areas, with slow growth and few eggs production. These are essentially the central experiences of rural poultry SMEs.

4.3. Feeding and nurturing chickens. A food nutrient is a substance needed by the bodies of animals to keep alive and be healthy (Ellie \& Rolfes, 2013). Foods contain five different nutrients, namely: proteins, minerals, vitamins, carbohydrates 
and fats and oils. Three main groups of food are body building foods, protective foods and energy foods, each of which contains certain nutrients (Brown, 2003). Chickens, in particular, need to eat food from all three of these groups every day. The body building foods contain proteins. The body uses protein to grow and to repair damage. Beans, nuts and peas contain plentiful proteins. Other foods rich in proteins often come from fish, meat, eggs and milk. The protective foods contain numerous vitamins and minerals. Chickens use the mineral calcium to build their bones, and use vitamin A to see at night (Waldroup, 2001). Fresh fruit and vegetables contain vitamins and minerals. Chickens are fond of these foods. They also eat the energy foods, which contain starch, sugar, fats or oils. These are fibre/roughage needed by the chickens for constipation prevention. In general, chickens need a balanced diet for their good health (Jones, 2007). Thus, chicken farmers need to ensure these food stuffs when nurturing chickens.

Cleanliness is vital to prevent chicken health problems. In addition, habitat of chickens should be clean (Bolton, 2015). Dirty crates, equipment and feed satchels should be kept away from the chicken houses. Very sick and dead chickens should be burned and buried away from living animals and people. Territories of chickens should also be disinfected.

\subsection{Management and environment in chicken} farming. Two vital aspects in poultry farming are chicken management and environmental control. Healthy chickens eat less, and produce more meat and eggs (Wethli \& Jensen, 2005). They are easy to look after, and cost less in expenses. Their main disease types are diarrhea, upper respiratory diseases, nervous signs and lameness. A disease spreads rapidly among chickens, because they are usually kept together, and share the same food and water bowls (Yan et al., 2007). Several factors contribute to diseases in chickens. The management disease types are caused by several factors, such as poor-quality food and water, poor hygiene and inadequate cleaning program. Leaking water bowls, rat and fly problems, overcrowding of chicks; chickens of mixed ages reared together, and no security measures to prevent people and animals from entering the chicken house are some of the causes of poultry diseases. When signs of diseases appear, the chickens must be treated urgently. The factors that may have led to the infections must be addressed to prevent the disease from occurring again. Treatment is suggested urgently when a disease occur in chickens. However, prevention of disease, where possible, should be ecouraged.

\section{Pricing}

Pricing refers to the process in which a business sets the fee at which it will sell its products and services (Yeoman, 2011). Its objectives should include achieving the financial goals of the company to ensure profitability; to fit the realities of the marketplace in order to ensure that the customers buy at that price; and to support a product's market positioning with being consistent with the other variables in the marketing mix (Han, Nunes \& Drèze, 2010). According to Yeoman and McMahonBeattie (2005), the level of price is influenced by the type of distribution channel used, the type of promotions used, and the quality of the product. Further, price will usually need to be relatively high if manufacturing is expensive; product is complex; scarce and valuable; distribution is exclusive; and the product is supported by extensive advertising and promotional campaigns, among others. Finally, a low cost price can be a viable substitute for product quality, effective promotions, or an energetic selling effort by distributors. Pricing in poultry farming is also influenced by these dynamics.

5.1. Market-related pricing. A market-related price is the price level which is in line or consistent with the average market price (Tenz, 2013). There may be some deviation from the average, but the difference should be small justifiable or small enough to be negligible. According to Park, Gu and Lee (2012), a market price refers to the commercial price for which a good or service is offered in the marketplace, which is a concept of interest predominantly to microeconomics. Market value and market price are equal only under conditions of market efficiency, equilibrium, and rational expectations.

5.2. Price variation. This refers to deviations occurring in the levels of prices for the same item (Tang, Smith \& Montgomery, 2010). Any significant difference in the price level from the market average is a price variation. It also varies the price from a market-related price. If the deviation leads to a market higher than the market-related price, the item is expensive. If it leads to a lower one, the item is cheap. However, marketing variation caused by additional features leading to higher quality does not constitute price variation. Rather, it may be considered value-for-money, meaning that the price set suits the value. 


\section{Uniqueness of chicken use in African culture}

Performance of rituals in African culture is vital to traditionalists (Jentile, 2010). The uses of chicken mentioned apply to rural and urban African chicken markets. In the traditional African sense, some chickens are also used for traditional rites. In particular, pure white and pure black chickens, which are scarce, are usually needed for this purpose. They can be priced higher than the rest. The black one, in particular, is occasional and often carries a much inflated price. These unique features enable the pricing of black and white chickens to be set higher. The modernized black chicken retailers often miss the opportunity to benefit on higher prices of these chickens. Failure to strategize seems to be one cause of losing opportunities.

\section{Methodology}

7.1. Design and method. The study was a qualitative phenomenological research, because it explored an issue as the central phenomenon (Creswell, 2014). The issue was the challenges of low-scale rural chicken farmers. The nine South African provinces have reputable colleges and government financial institutions which interact with farmers on a daily basis. This study focused on the rural chicken SMEs owners who could be identified and the provincial institutions mentioned. They were contacted regarding the question of rural chicken entrepreneurs' performances and reasons for their levels of performances. In the Limpopo and North-West provinces, interviews were carried out by the researchers, while in other seven provinces, the provincial institutions' marketing divisions carried out the interviews and supplied the scripts of the responses.

7.2. The sample. The sample consisted of 23 obtainable and former rural chicken SME owners. The former owners were those whose businesses had failed. They were identified mainly by the institutions which funded and/or interacted with them regularly. The study considered only those who were willing to share their experiences. As a qualitative research, it did not intend to generalize the results, but to elucidate real issues of concern (Neuman, 2003). The idea was to purposefully select specific subjects to examine in order to understand the issues under consideration.

7.3. The data. The data were text data given as statements of personal experiences on running a chicken farm. These were statements of what transpired during their entrepreneurial effort in chicken farming.

7.4. Data collection. The data collection exercise occurred over a five-week period. Some chicken farmers were interviewed using a scripted unstructured interview guide, which was piloted and corrected. In some cases, probing became necessary and was done immediately. The unstructured interview approach allowed the participant to openly express views on the subject without being confined to specific choices for answers (Creswell, 2014). Scripting of questions allowed the interviews to follow a similar pattern with the same topics. The unstructured, open-ended interviews enabled the researchers to identify the major issues while retaining the flexibility for the participants to abundantly express their personal experiences regarding chicken farming.

7.5. Data analysis. Analyses commenced after receiving the responses in scripts. Names of the respondents were not included to assure anonymity. It identified the themes from the interviews and the patterns molded. The units of meanings were used in the scripts submitted. The course of analyzing the collective terms, developing patterns, and inclusive themes led to an understanding of the fate of rural chicken SMEs.

\section{Results}

The respondents shared their problems and challenges they experienced, and their prior impressions about chicken farming.

Over $82 \%$ of the respondents had successfully sold indigenous chickens in the informal markets in their rural villages and made huge profits. They were survivalists and micro-business owners, and not previously registered as business owners. They also had no previous experiences of having to pay business tax.

These were recruited through government support to invest in chicken farming due to their perceived successes. The ones with no previous experiences joined a call by government-aligned funders for willing chicken entrepreneurs. They were financially and materially supported. However, they were not educationally empowered to know the dynamics of formal chicken business. It was clear that when they participated, many of them lacked business skills and business knowledge.

With the scheme they were entering as government supported SMEs, they had to select an accountant for dealing with their business taxes. These rural farmers perceived the business sponsorship moneys as a way of government to force them to pay taxes.

8.1. Improving the soil with chickens. Also, only about $17 \%$ knew about the soil suitable for chickens. The others were not even convinced that it is worth investing on the soil preparation.

8.2. Chicken breeds. The respondents were not knowledgeable in the different breeds of chickens. They knew chickens to be mainly meat and egg suppliers. 
They all knew about some uses of the feathers. However, only about $4 \%$ had planned to be involved in feather supply, but did not know how to prepare feathers for business and where feathers could be sold.

8.3. Feeding and nurturing chickens. The respondents indicated their boredom with regard to feeding chickens with various types of food for various nurturing objectives. The idea of the five different nutrients and the three groups of foods seemed to have frustrated them. They all felt that these were wasting their time and money. They considered the money that they were required to pay for the nurturing of chickens as unnecessary. Regarding the cleaning of chicken habitations, about $26 \%$ did some basic cleaning. However, none of them used agricultural materials prescribed for preventing chicken diseases.

8.4. Management and environment in chicken farming. The respondents were asked about the way they treated chicken diseases. Surprisingly, the fact that chickens could have diarrhoea, upper respiratory diseases, nervous signs and lameness shocked all the respondents. The respondents were also surprised that the chicken diseases could spread to other chickens. They all thought that indigenous chickens did not fall sick. Also, the respondents were surprised that poor-quality food and water, poor hygiene and inadequate cleaning program could cause chicken diseases. Also, they also did not know that chicken farming could be ruined by leaking water bowls, rat and fly problems, overcrowding of chicks, chickens of mixed ages reared together, and people and animals entering the chicken house could cause poultry diseases.

8.5. Pricing. All the respondents knew about chickens use in cultural rites. However, none of them could link scarcity of some chickens and cultural value to adjust prices of some of the chickens. Also, they all found the prices of chickens as being determined by weight, which was what the rural market understood. Also, for them the chickens were still being reared for eggs and meat.

\section{Discussions}

The findings show that, as highlighted in the introduction by Brink, Cant and Ligthelm (2008), the rural poultry SMEs encountered environmental, financial and managerial challenges in managing their businesses. The details of these classes of challenges are unpacked and discussed in the next paragraphs.

The rural chicken farmers recruited to join the formal mainstream market seem to be lacking an entrepreneurial acumen. Their problems and challenges in chicken farming were enormous. The transition from informal market to formal markets has not been smoothened with proper empowerment. The formal markets required registration according to the rules of the regulator. They were also required to pay taxes, which they did not have to do in their past businesses. These taxes and other payments reduced their profits.

The rural poultry SME owners had started to perceive their recruitment to the formal market as a trap by government agencies to force or trick them to pay taxes. They were not given the information to understand the new business contexts. They entered the formal market with no business skill and knowledge. They also knew little about competition in business.

The formal requirement of hiring accountants was also perceived as policing to ensure tax compliance. Apparently, taxes were burdening their pockets. As a result, some were even considering the option to leave business, because it was their easy way to escape the perceived government tax trap. Hence, there was a chance for more failure.

\subsection{Improving the soil suitability for chickens.} The rural poultry SMEs did not know that poultry farming could be having any soil requirements. This is because they did not know that some soils could be unsuitable for chickens. As a result, they did not invest on the appropriate soil preparation for their chickens.

9.2. Chicken breeds. Apparently, the rural poultry SMEs only recognized colors and genders of chickens. They did not know about the different breeds of chickens and the yields available in the different types of chicken breeds. For most of them, eggs and meat were the only clear products they knew could come from their businesses. Only few of them had the idea to also produce feathers, but lacked knowledge on where to start that trade.

9.3. Development of chickens. The issue of investing some money to nurture the chickens was new to many rural poultry farmers. It also bothered them. They had no idea about the nutrients required for chickens in the farming business. They thought of these considerations as time and money wastages. Their chickens were also bred in untidy habitations. There were also no disease preventions in the grooming of these chickens.

9.4. Management of chicken farms. The poultry farmers from rural areas did not prevent or cure diseases in chickens. They also did not know that the chickens could fall sick, or could need 
healthcare treatment. They were surprised that interactions with other animals could compromise the quality of their chickens. These farmers' leading challenge was, therefore, that they were, for the first time, required to compete in a formal market where healthy eating of chickens is a serious concern. Their chickens and the living areas of these chickens were not hygienic. Furthermore, the water the chickens drank, the poor-quality food they ate, and every filthy materials around their poultry make the chickens and their businesses vulnerable. This was not a familiar practice for the rural poultry SMEs.

9.5. Pricing. The rural farmers are all Africans who knew about the use of chicken in the cultural rites. However, they could not connect their poultry business with strategies of pricing in the applicable context. The pricing of their chickens was limited to weight, which was dwarfed by the unhygienic conditions of the chickens' environments. Hence, the pricing opportunity that existed was not exploited. Thus, even where opportunities existed, the rural chicken farmers could not use cultural advantages for pricing their chickens.

\section{Implications and recommendations}

There are visible differences between SMBs and SMEs, as well as between formal and informal markets. SMBs are informal and not registered with any regulator, while SMEs are registered. The rural poultry SMEs were not empowered for formal businesses and markets. They also lacked knowledge of modern farming of chickens even though they were in chicken business. The study recommends that:

- rural chicken famers should be trained in chicken farming before being registered as formal businesses;

- financing of chicken business should be based on proven training in chicken business;

- chicken regulators should close (unhygienic);
- chicken farms which compromise the health of consumers of chicken;

- chicken farmers should be trained to be entrepreneurial.

\section{Conclusion}

Transition of contexts in business has potential to make a difference in results. The rural poultry farm owners operated as SMBs, with no pressure to register their business. However, when entering the formal market, they had to understand some formal dynamics such as soil preparation, tax payment, differences in breeds of chickens, breeding of chickens, chicken diseases, and many threats to the chicken farming business. The causes of their failures were fuelled by the sudden change which could be mitigated by slower steps towards formalizing the businesses. Such steps appeared as recommendations in previous section.

\section{Limitations and future research}

The study was limited to the rural chicken farmers who could be contacted and willing to participate in the study, who also could be contacted through the institutions mentioned. Many rural farmers cannot be reached due to unavailability of their register, inadequate communication systems, and unwillingness or inability to respond to questionnaire for the interviews. There should be new methods for locating these SMEs, and for searching for more information from them.

\section{Acknowledgements}

We would like to thank provincial institutions and agricultural colleges which agreed to assist. This research was supported by the Department of Statistics and Operations Research of the Sefako Makgatho Health Sciences University.

\section{References}

1. Abor, J. \& Quartey, P. (2010). Issues in SME development in Ghana and South Africa, International Research Journal of Finance and Economics, 39, pp. 219-228.

2. Agle, B., Donaldson, T., Freeman, R., Jensen, M., Mitchell, R. \& Wood, D. (2008). Dialog: Towards superior stakeholder theory, Business Ethics Quarterly, 18(2), pp. 153-190.

3. Appleby, M.C., Mench, J.A. \& Hughes, B.O. (2004). Poultry behaviour and welfare. Wallingford: CABI Publishing.

4. Argyris, C. (1998). Managers, workers, and organizations, Society, 35, pp. 242-246.

5. Bolton, T. (2015). The state of the South African poultry industry. Supermarket \& Retailer, March 2015, Poultry, pp. 17-23.

6. Brink, A., Cant, M. \& Ligthelm, A.A. (2003). Problems experienced by small businesses in South Africa, A paper for the Small Enterprise Association of Australia and New Zealand, $16^{\text {th }}$ Annual Conference, Ballarat, $28^{\text {th }}$ Sept to $1^{\text {st }}$ Oct, 2003.

7. Brown, L.R. (2003). Raising land productivity: Raising protein efficiency, Plan B: Rescuing a planet under stress and a civilization in trouble. New York: W.W. Norton \& Co. 
8. Chen, Y.J., Yan, S.M., Li, H.Y., Cao, P. \& Xu, Z.X. (2008). Effect of vitamin A and vitamin E on growth performance and immune functions in broilers, Chinese Journal of Inner Mongolia Agricultural University, 29(1), pp. 14-19.

9. Creswell, J.W. (2014). Research design qualitative, quantitative, and mixed methods approaches, 4th edition. Thousand Oaks, CA: Sage Publications.

10. Cullinan, C., Bline, D., Farrar, R. \& Lowe, D. (2008). Organization-harm vs. organization-gain ethical issues: An exploratory examination of the effects of organizational commitment, Journal of Business Ethics, 80(2), pp. 225-235.

11. Deeb, N., Shlosberg, A. \& Cahaner, A. (2002). Genotype-by-environment interaction with broiler genotypes differing in growth rate, Poultry Science, 81(10), pp. 1454-1462, October.

12. Dzansi, D.Y. (2004). Social responsibility of SMMEs in rural communities, Unpublished doctoral thesis. Pretoria, South Africa: University of Pretoria.

13. Ellie, W. \& Rolfes, S.R. (2013). Understanding nutrition, 13th edition. Wadsworth, Cengage Learning.

14. Foer, J.S. (2009). Eating animals, New York: Little, Brown and Company.

15. Gagoitseope, P.K. \& Pansiri, J. (2012). Evaluation of critical success factors for developing small and mediumsized enterprises in Botswana, Journal of African Business, 13(1), pp. 51-61.

16. Gill, A. \& Biger, N. (2012). Barriers to small business growth in Canada, Journal of Small Business and Enterprise Development, 19(4), pp. 656-668.

17. Han, Y., Nunes, J. \& Drèze, X. (2010). Signaling status with luxury goods: The role of brand prominence, Journal of Marketing, 74(4), pp. 15-30.

18. Hauser, M., Cushman, F., Young, L., Jin, R. \& Mikhail, J. (2007). A dissociation between moral judgments and justifications, Mind \& Language, 22(1), pp. 1-21, February.

19. Jenkins, H. (2006). Small business champions for corporate social responsibility, Journal of Business Ethics, 67(3), pp. 241-256.

20. Jentile, T.E. (2010). Personal conversation on African religion, death and mourning rituals, Mamelodi Township, Pretoria, October.

21. Jones, F.T. (2007). A broad view of arsenic, Poultry Science, 86(1), pp. 2-14.

22. Ladzani, W.M. \& Van Vuuren, J.J. (2002). Entrepreneurship training for emerging SMEs in South Africa, Journal of Small Business Management, 40(2), pp. 154-161.

23. Lepoutre, J. \& Heene, A. (2006). Investigating the impact of firm size on small business social responsibility: A critical review, Journal of Business Ethics, 67, pp. 257-273.

24. Mantel, S. (2005). Choice or perception: How affect influences ethical choices among salespeople, Journal of Personal Selling \& Sales Management, 13, pp. 43-56, Winter.

25. Mark-Ungericht, B. \& Weiskopf, R. (2007). Filling the empty shell. The public debate on CSR in Austria as a paradigmatic example of a political discourse, Journal of Business Ethics, 70, pp. 285-297.

26. McCuen, R. \& Shah, G. (2007). Implications to ethics educations of recent neuroscience research on emotions, Journal of Leadership Studies, 1(3), pp. 44-56.

27. Moore, G. \& Spence, L. (2006). Editorial: Responsibility and small business, Journal of Business Ethics, 67, pp. 219-226.

28. Moustakas, C. (1994). Phenomenological research methods. Thousand Oaks, CA: Sage.

29. Neuman, W. (2003). Social research methods: Qualitative and quantitative approaches. Boston: Allyn and Bacon.

30. Parboteeah, K., Hoegl, M., Cullen, J. (2008). Ethics and religion: An empirical test of a multidimensional model, Journal of Business Ethics, 80, pp. 387-398.

31. Park, J., Gu, B., Lee, H. (2012). The relationship between retailer-hosted and third-party hosted WOM sources and their influence on retailer sales, Electronic Commerce Research and Applications, 11(3), pp. 253-261.

32. Perrini, F., Russo, A. \& Tencati, A. (2007).CSR strategies of SMEs and large firms. Evidence from Italy, Journal of Business Ethics, 74, pp. 285-300.

33. Revell, A. \& Blackburn, R. (2007). The business case for sustainability? An examination of small firms in the UK's construction and restaurant sectors, Business Strategy and the Environment, 16, pp. 404-420.

34. Rogerson, C. (2004). The impact of the South African government's SMME programs: a ten-year review (19942003), Development Southern Africa, 21(5), pp. 765-784, December.

35. Sakkas, D. (2002). The European observatory for small and medium-sized enterprises: Research environment and innovation in Greek manufacturing, KEPE Center for Planning and Economic Research, Report 22. Retrieved 4, 2010, from http:/www.kepe.gr/eng/reports.htm.

36. Sherwin, C., Richards, G. \& Nicol, C. (2010). A comparison of the welfare of layer hens in four housing systems used in the UK, British Poultry Science, 51(4), pp. 488-499.

37. Tang, Z., Smith, M.D. \& Montgomery, A. (2010). The impact of shopbot use on prices and price dispersion: Evidence from online book retailing, International Journal of Industrial Organization, 28(6), pp. 579-590.

38. Timmons, J.A. \& Spinelli, S. (2004). New venture creation: Entrepreneurship for the 21 st century. $6^{\text {th }}$ edition. Boston, MA: Irwin McGraw-Hill.

39. Trenz, M. (2013). The effect of consumer reviews on vendor-related and market-related price sensitivity, ECIS 2013 Research in Progress. Paper 13. Available at: http://aisel.aisnet.org/ecis2013_rip/13. 
40. Thwala, J.D., Pillay, A.L. \& Sargeant, C. (2001). The influence of urban/rural background, gender, age \& education on the perception of and response to dreams among the Zulu South Africans, South African Journal of Psychology, 30(4), pp. 1-5.

41. Van Kaam, A. (1966). Existential foundations of psychology. Oxford: Duquesne University Press.

42. Waldroup, P.W. (2001). Dietary nutrient allowances for chickens and turkeys, Feedstuffs, 73(29), pp. 56-65.

43. Wethli, E. \& Jensen, H.A. (2005). Chickens for profit: Starting a small poultry business. London: ITDG Publishing.

44. Yan, S.M., Feng, Y.M., Zhang, H.Q. \& Shi, B.L. (2007). Effects of vitamin A and vitamin D on metabolism of calcium and phosphorous in broilers, Chinese Journal of Animal Nutrition, 19(3), pp. 218-224.

45. Yeoman, I. (2011). The changing behaviours of luxury consumption, Journal of Revenue and Pricing Management, 10, pp. 47-50.

46. Yeoman, I. \& McMahon-Beattie, U. (2005). Luxury markets and premium pricing, Journal of Revenue and Pricing Management, 15(10), pp. 319-328.

47. Zyphur, M. (2006). Acting ethically in the face of threat: The effects of identity and personality, Doctoral Dissertation Tulane University. 